\title{
KARTKA OCALONA Z OGNIA. LIRYKI POLOZAŃSKIE ADAMA MICKIEWICZA: DRZEWO I [WSEUCHAĆ SIĘ W SZUM WÓD GEUCHY...]
}

\section{Ocalony manuskrypt}

Kartkę z lirykami prywatnymi Adama Mickiewicza pt. Drzewo i [Wstuchać się w szum wód głuchy...] najprawdopodobniej ocalił przed spaleniem, z rąk poety, Aleksander Chodźko. Fakt ten został odnotowany w Kronice życia i twórczości Adama Mickiewicza wraz z odwołaniem do informacji Władysława Mickiewicza:

17 lub 18 czerwca ... ok. 10 października?

Saint-Germain-en-Laye. Powstanie wierszy: Drzewo i Wstuchać się w szum wód...

Tekst z notatką: „Pisane w Saint-Germain” ocalił A. Chodźko, w którego obecności Mickiewicz palił kiedyś bruliony wierszy przepisanych. Na podstawie wzmianki o Saint-Germain Wł. Mickiewicz sądził, że uratowana kartka pochodzi z wakacji $1842 \mathrm{r}^{1}$

W Saint-Germain-en-Laye Mickiewiczowie przebywali od połowy czerwca do ok. 10 października 1842 roku, skąd Mickiewicz dojeżdżał do Paryża na wykłady oraz w związku z obowiązkami w Kole Sprawy Bożej. Dwa wiersze znajdujące się na ocalonej wyrwanej z ognia kartce

1 Zofia Makowiecka, Kronika życia i twórczości Mickiewicza. Październik 1840-maj 1844. Mickiewicz w Collège de France, Warszawa 1968, s. 299-300. Kronika powołuje się na źródło: Władysław Mickiewicz, Żywot Adama Mickiewicza, Poznań 1894, t. III, s. 168. 
powstały najprawdopodobniej podczas letniego pobytu w SaintGermain-en-Laye w 1842 roku. Alina Witkowska napisała:

Mickiewicz lubił St.-Germain-en-Laye [...]. Miewał tam chwile spokoju i skupienia, a nawet powrócił do poezji, pisząc wiersze Drzewo i Wstuchać się w szum wód gluchy...2.

Badacze przyjmują tę datę powstania utworów, choć nie można wykluczyć, że wiersze powstały podczas któregoś z późniejszych pobytów w Saint-Germain (w lutym 1843, czerwcu 1846 lub pod koniec 1846, o czym pisał Czesław Zgorzelski³).

Autograf z wierszami prawdopodobnie zaginąt ${ }^{4}$, trudno o jakąkolwiek weryfikację ustaleń edytorskich Wacława Borowego, który najdokładniej, z autopsji, opisał manuskrypt:

Jest to półarkusik niebieskawego papieru, przez pół złożony $(21 \times 13,3 \mathrm{~cm})$. Kawałek kartki pierwszej wycięto. Wyblakłym atramentem u góry 1-ej str. wypisał poeta urywek [...] [Drzewo - E.Sz.-P.] i następny [Wstuchać sie w szum wód głuchy], przedzieliwszy je krzyżykiem. Pozostałe 3 stroniczki zostały puste. Poeta widocznie przepisywał z jakiegoś brulionu, bo przy wierszu przedostatnim drugiego urywka dodał: „(nie wyczytam)”,

2 Alina Witkowska, Saint-Germain-en-Laye, w: Jarosław Marek Rymkiewicz, Dorota Siwicka, A. Witkowska, Marta Zielińska, Mickiewicz. Encyklopedia, Warszawa 2001, s. 479. Autorka hasła powołuje się na: Maria Dernałowicz, Kronika życia i twórczości Mickiewicza. Czerwiec 1834 - październik 1840, Warszawa 1996; Zofia Makowiecka, Kronika życia i twórczośsi Mickiewicza. Październik 1840 - maj 1844, dz. cyt.

3 Czesław Zgorzelski, Uwagi edytorskie $i$ odmiany tekstu, w: Adam Mickiewicz, Dzieła wszystkie, pod red. Konrada Górskiego, t. I, cz. 3: Wiersze 1829-1855, oprac. Cz. Zgorzelski, Wrocław 1981, s. 378.

4 „Autograf (A) przed wybuchem wojny 1939 r. przechowywany był w Uniwersytecie Stefana Batorego w Wilnie; stanowił własność Dziekanatu Wydziału Sztuk Pięknych jako rkps $\mathrm{nr}$ 1, pochodzący z daru prof. A. Wrzoska w r. 1919. Dziś jest zagubiony. Wszystkie informacje o nim edycja czerpie z odnotowań Borowego, który oglądał go przed wojną, przygotowując tekst urywka do WS [Wydania Sejmowego - E. Sz.-P.] (rkps BNar II 7499/3, k. 603-604 i II 7500/3, k. 721)". Czesław Zgorzelski, Uwagi edytorskie i odmiany tekstu, dz. cyt., s. 376-377.

5 Tamże, s. 377. 
Powyższe informacje pozwalają przyjąć, że Mickiewicz „widocznie” przepisywał wiersze z jakiegoś brulionu (sformułowanie ,widocznie” można rozumieć w znaczeniu: prawdopodobnie, być może; Borowy nie rozstrzygnął kwestii słów pochodzących - jak twierdził edytor - od poety: „nie wyczytam” w sposób jednoznaczny, należy zatem potraktować te ustalenia jako hipotetyczne). Autograf składał się łącznie z 4 stron (złożona na pół kartka papieru). Na pierwszej stronie, od góry były zapisane dwa liryki, kawałek pierwszej strony został odcięty, a kolejne strony pozostały puste. Mickiewicz nie otaczał swej prywatnej twórczości jakąś specjalną troską, hojną dłonią rozdawał swoje teksty jako pamiątki albo na czyjąś prośbę, aczkolwiek konsekwentnie chronił je przed szeroką publicznością (i przed opublikowaniem) ${ }^{6}$. Wydaje się, że rękopisy utworów prywatnych największą wartość miały dla Mickiewicza w trakcie pisania, inaczej mówiąc w trakcie ,wydobywania” sensu (wysławiania), tworzyły wówczas nie tyle przestrzeń opisu, co przestrzeń wyrażania stanów głębokich, później takie rękopisy mogły zostać w lekkim geście podarowane lub oddane na czyjąś, indywidualną prośbę, ale były konsekwentnie niepublikowane, a częstokroć skrywane. Wielokrotnie pisał na ten temat Zgorzelski:

Luźne kartki drobnych utworów, rozdzielane z hojnością królewskiego gestu przez poetę $\mathrm{w}$ różne strony świata, między ludzi z otoczenia nie zawsze najbliższego, mniej miały szans na częściowe choćby ocalenie. Daremnie by dziś zmierzać do zestawienia pełnej listy strat, jakeśmy wskutek owej szczodrobliwości - ponieśli. Niewiele o nich dziś wiemy ${ }^{7}$.

\footnotetext{
6 Jak pisał Czesław Zgorzelski: „Sam poeta nie troszczył się nadmiernie o zachowanie swych autografów w całości. Owszem, znał ich cenę, wiedział, czym mogą się stać dla przyszłych pokoleń, ale rozporządzał rękopisami ze swobodną beztroską, obdarzając nimi przyjaciół, a nawet ludzi spotykanych przygodnie. Proszącym o pamiątki nie umiał odmawiać; cieszył się zapewne ich radością, uzyskaną tak niewielką - zdawałoby się - ofiarą z jego strony. Wyjmował z kuferka czy z szuflady arkusze, kartki lub zeszyty; czasem wręczał je w całości, kiedy indziej - niestety! - brał nożyce i odcinał skrawki zapisanego papieru lub wyrywał nieopatrznie stronice z zeszytu, zamieniając swe autografy w ulotne pamiątki, tyleż cenne, co kruche i łatwe do zagubienia!”. Wstęp, w: Wiersze Adama Mickiewicza w podobiznach autografów. Część pierwsza: 1819-1829, oprac. Cz. Zgorzelski, Wrocław 1973, s. 5.

Tamże, s. 6.
} 
Jak wynika z opisu, wiersz Drzewo znajdował się u góry pierwszej strony, a bezpośrednio pod nim, oddzielony krzyżykiem tekst liryku [Wstuchać się w szum wód głuchy...], dolny kawałek kartki został odcięty, nie ma informacji, czy mógł być zapisany, czy też nie. Te dwa liryki w tradycji interpretacji traktowane są dość marginalnie, między innymi z powodu uznania ich za nieukończone. Wacław Borowy określał te wiersze mianem urywków, w ten sposób były i są odczytywane i nazywane w tradycji badawczej. Urywkowość tych liryków, co należy podkreślić, jest nośnikiem sensów poetyckich, a nie usterką.

Mickiewicz oddzielał zwykle krzyżykiem pewne całości semantyczne, niemniej decyzja Władysław Mickiewicza (pierwszego edytora omawianych liryków) o opublikowaniu obu tekstów jako jednego utworu powstałego w Saint-Germain, zasługuje na uwagę ${ }^{8}$. Do tej decyzji jeszcze powrócę, gdyż jej uzasadnienie może mieć wartość hermeneutyczną. Mówimy o dwóch wierszach szczególnych, także z tego powodu, że autografy są obecnie niedostępne (uznane za zaginione). Nie zostały opublikowane w Wierszach Adama Mickiewicza w podobiznach autografów. Lektura musi zatem być rekonstrukcyjna, detektywistyczna, każdy trop wydaje się znaczący, dlatego należy wziąć pod uwagę wszystkie niuanse edytorskie, komentarze, których wartość (w obliczu braku autografów) jest doniosła. Czesław Zgorzelski napisał:

Autor Żywota zaznaczył [...], że zapis poety jest „,bez daty, ale ze wzmianką, że «pisany w Saint-Germain»", a w przypisku dodał informację, której nie związał jednak bezpośrednio i konkretnie z historią autografu Drzewa: „Mickiewicz palił raz w obecności Aleksandra Chodźki bruliony przepisanych wierszy, Chodźko jednę ćwiartkę uratował od ognia, który pożarł wiele innych świstków".

Akt palenia takich osobistych wierszy jak Drzewo i [Wstuchać się w szum wód głuchy...] staje się czymś w rodzaju „samospalenia”; być może dlatego widok artysty wrzucającego do ognia swoje dzieła jest

$8 \quad$ Władysław Mickiewicz, dz. cyt., s. 168.

9 Czesław Zgorzelski, Uwagi edytorskie i odmiany tekstu, dz. cyt., s. 377. 
zawsze przejmujący. W wymiarze fenomenologicznym to, co spalone, jest śladem, znakiem, aktem wobec siebie, zwłaszcza w przypadku liryki osobistej.

Powstanie tych dwóch liryków można chyba łączyć (przypuszczenie przyjęte również przez Alinę Witkowską) ze słowami Mickiewicza z listu pisanego z Paryża do Towiańskiego około 12 października 1842 roku:

W ostatnich dniach pobytu w St.-Germain, 4, 5, 6 octobra, byłem ja w wielkim podniesieniu ducha; przypomniałem, że miałem dawniej te stany, ale o nich całkiem straciłem był pamięć i teraz dopiero dziwnie wróciły. Ale było to uczucie swobody i mocy, bez żadnej myśli, bez kierunku, bez chęci. Dawniej puściłbym je na poezję, teraz czekałem kierunku ${ }^{10}$.

Ten interesujący, epistolarny trop może świadczyć, że liryki, datowane na 1842 rok, były realizacją wyrażonych w liście zamierzeń oraz „nieokreślonego” stanu natchnienia. Powrót - jak go określa Mickiewicz - „dziwny” powrót, był w jego przeświadczeniu powrotem do dawnych stanów natchnienia, czyli ,wielkiego podniesienia ducha”. W takim świetle ujmowała te epistolarne refleksje Zofia Stefanowska:

Sądzę, że mamy tu jedyny w swoim rodzaju opis natchnienia, które nawiedzało poetę po długim czasie nieobecności ${ }^{11}$.

Poeta nie wspominał Towiańskiemu, że jakieś utwory napisał przypuszczam, że w jego mniemaniu nie było o czym mówić (o lirykach lozańskich także w listach milczał) - wiersze mogły więc powstać mniej więcej w tym samym czasie co list do Towiańskiego lub w jego chronologicznej bliskości. Zdaniem Stefanowskiej:

10 Adam Mickiewicz, Listy. Część trzecia: 1842-1848, w: Dzieła (Wydanie Rocznicowe), t. XVI, [oprac. Maria Dernałowicz, Elżbieta Jaworska, Marta Zielińska], Warszawa 2004, s. 104.

11 Zofia Stefanowska, Mickiewicz - tradycja i nowatorstwo, w: Próba zdrowego rozumu. Studia o Mickiewiczu, wyd. II zmienione, Warszawa 2001, s. 349. 
Jako wynik tego niezwykłego momentu powstały jednak nie wiersze, ale, co trudno spokojnie mówić, słowa (francuskie) Napoleona, który zwracał się do Francuzów [... $]^{12}$.

Mickiewicz wprawdzie zapisał we wspomnianym liście do Towiańskiego (z 12 października 1842) słowa Napoleona (w postaci notaty, w podobnym stylu napisał ich wiele), ale nie przesłał Towiańskiemu żadnych wierszy - zresztą nigdy, zapewne z różnych powodów, tego nie robił, konsekwentnie liryki prywatne ukrywał. Intymność wydaje się ciągle niedocenioną kwestią bezpośrednio związaną z późną, niepublikowaną przez poetów, liryką romantyczną. Z listu Mickiewicza do Towiańskiego wynika, że owo ,wielkie podniesienie”, które mogłoby zaowocować poezją, miało miejsce - zgodnie ze słowami Mickiewicza: „4, 5, 6 octobra”, ale poeta ,czekał kierunku” i w nocy ,z dnia siódmego na ósmy” poczuł przy sobie ,ducha Napoleona” i napisał (po francusku) słowa, w wyniku swego rodzaju iluminacji. Są one (,,słowa Napoleona”) zamieszczone w liście, ale mają swój „kierunek” i retoryczną, perswazyjną strategię, „nie zgadzają się” z wcześniejszym, epistolarnym opisem stanu, który w przeszłości owocował natchnieniem i twórczością poetycką. Być może jednak Mickiewicz skierował się właśnie wtedy ku liryczności, której de facto nigdy nie porzucił. Pozostała w każdym razie kartka, na której zanotował dwa liryki. Kartka ocalona jedynie w komentarzach i omówieniach edytorskich, dzięki czemu jest pewnikiem pośród niezliczonych hipotez i przypuszczeń, które wbrew pozorom, mimo wszystko, mają swoją wartość.

Powstanie tych wierszy weryfikuje tezę, że Mickiewicz towiańczyk lirycznie zamilkł, że przestał być poetą lirycznym. Liryki, które ocalały, świadczą o tym, że jednak nie, poza tym z perspektywy liryki (tego, co mogło zostać spalone, rozdane, zaniechane) można na towianizm, a także na wykłady paryskie Mickiewicza spojrzeć w znacznie szerszym kontekście interpretacyjnym. W badaniach zwykło się rozdzielać poszczególne sfery życia i twórczości poety, w tym towianizm Mickie-

\footnotetext{
12 Tamże.
} 
wicza od twórczości artystycznej. Stawia się wyraźną cezurę pomiędzy towianizmem i lirycznością, formułując chociażby tezy o zamilknięciu Mickiewicza. Ta kartka ocalona z ognia może być tylko jedną z wielu kartek, jakie mogły zostać zapisane. Należy zastanowić się nad lirycznością w szerszym kontekście: w związku z tożsamością osoby twórcy, która może być wyrażana w sztuce, w różnorodnych formach i kształtach wypowiedzi, nie tylko pisemnej. Działalność Mickiewicza w obrębie tzw. towianizmu czy też prelekcje paryskie również charakteryzuje podmiotowy, by nie powiedzieć liryczny, charakter wypowiedzi oraz żywioł improwizacyjny, o którym pisał m.in. Wiktor Weintraub $^{13}$. Zatem to, co wydaje się pozornie sprzeczne, może współistnieć oraz się nawzajem oświetlać.

\section{Manuskrypt jest całością}

Ocalony z ognia manuskrypt zasługuje na uwagę z różnych powodów. Przede wszystkim należy się upomnieć o autograf jako całość, złożoną z dwóch tekstów, a także zastanowić się nad sąsiedztwem obu utworów. Liryki powstały najprawdopodobniej w tym samym czasie, pod wpływem podobnych emocji. Łączy je specyfika procesu twórczego, wyrażają podobny stan wewnętrzny, podobny rodzaj napięcia. Manuskrypt zdaje się rozstrzygać kwestie edytorskie - oba teksty mianowicie powinny być publikowane jeden pod drugim, w sąsiedztwie, które wyznacza wspólna kartka (nie we wszystkich edycjach zachowuje się ,spójność” narzuconą przez autograf); jest to fakt istotny dla interpretacji. Analogiczny problem wyłania się z edycji liryków lozańskich, w których „rozdziela się” teksty zapisane na jednej, wspólnej kartce papieru, a następnie umieszcza w różnej kolejności i w różnym sąsiedztwie, nie zawsze odpowiadającym kolejności nadanej poszczególnym utworom przez autora, czyli zgodnie z rękopisem. Model lektury, który nazywam brulionowym, jest projektem lektury symultanicznej, zgodnej z procesem twórczym oraz ze sposobami zapisywania

\footnotetext{
13 Wiktor Weintraub, Improwizacja w świecie romantycznym, w: tegoż, Poeta i prorok. Rzecz o profetyzmie Mickiewicza, Warszawa 1998.
} 
utworu (utworów) przez autora, a także uwzględniającej inne teksty i rodzaje działalności twórczej poety w tym czasie.

Można by sobie wyobrazić, że liryki na kartce były zapisane w następujący sposób:

Drzewo

\section{Pisano w St. Germain}

I z drzewa wysłużyło już zostać robakiem,

Już świeci się po wierzchu liściem niejednakiem,

Barwistą wróżbą liszki, wierzchołki jak rożki

Bodzie w górę i liśćmi przebiera jak nożki,

Gdy wiatr wionie, że nie wiesz, czy dziecko w kolebce,

Czy gąsienica szybko mącąca nogami,

Czy wąż $[\ldots \ldots \ldots \ldots]^{14}$

Wsłuchać [się] w szum wód głuchy, zimny i jednaki

I przez fale rozeznać myśl wód jak przez znaki,

Dać się unosić wiatrom, nie wiedzieć gdzie lotnym,

I zliczyć każdy dźwięk w ich ruchu kołowrotnym,

Wnurzyć się w łono rzeki z rybami...

Ich okiem niewzruszonym jak gwiazda... ${ }^{15}$

Czy Mickiewicz odciął zapisany, czy niezapisany kawałek papieru, na którym znajdował się autograf wierszy? Nie wiadomo. Na złożonej na pół kartce, dzięki czemu uzyskano cztery strony (Mickiewicz często tak składał kartki), znajdowały się dwa liryki. Świadomie nie nazywam ich urywkami, ponieważ urywkowość, a w szerszym kontekście brulionowość jest w tych utworach nośnikiem sensu poetyckiego, nie stanowi wady czy deficytu sensu.

14 Adam Mickiewicz, Wiersze, w: Dzieła (Wydanie Rocznicowe), t. I, [oprac. Czesław Zgorzelski], Warszawa 1993, s. 415.

15 Tamże. Przypomnę, Wacław Borowy objaśniał, że przy przedostatnim wersie było napisane ,nie wyczytam”; być może z tego powodu w dwóch ostatnich wersach nastąpiło załamanie rytmu (dziewięciozgłoskowiec). 
Komentatorzy w najważniejszych edycjach dzieł Mickiewicza przyjmują, że pierwodruk wiersza Drzewo znajduje się w Żywocie Adama Mickiewicza, ale za poprawne uznają ustalenia edytorskie Wacława Borowego, który opracował autograf. W pierwodruku utwór został opublikowany przez Władysława Mickiewicza jako jeden wiersz, a raczej ,szkic do wiersza" ${ }^{16}$, w następującej postaci:

Drzewo.

I z drzewa wysłużyło już zostać robakiem.

Już świeci się powierzchu liściem nie jednakim, Barwistą wróżbą liszki, wierzchołki jak Różki

Bodzie w górę i liśćmi przebiera jak nożki,

Gdy wiatr wionie, że nie wiesz, czy dziecko w kolebce,

Czy gąsienica szybko mącąca nogami.

Wsłuchać w szum wód głuchy, zimny i jednaki

I przez fale rozeznać myśl wód jak przez znaki,

Dać się unosić wiatrom nie wiedzieć gdzie lotnym

I zliczyć każdy dźwięk w ich ruchu kołowrotnym,

Wnurzyć się w łono rzeki z rybami,

Ich okiem niewzruszonem jak gwiazda

Nie wyczytasz... ${ }^{17}$

W tej publikacji słowa ,nie wyczytasz” są integralną częścią utworu; Wacław Borowy inaczej je zinterpretował, uznał także, że mamy do czynienia z dwoma lirykami. Trudno dzisiaj o jakąkolwiek weryfikację $\mathrm{z}$ autografem, pozostaje tylko zaufanie Borowemu i jego hipotezie, że w nawiasie było „nie wyczytam”, co oznaczałoby, że Mickiewicz jedynie przepisywał wiersze $\mathrm{z}$ innego brulionu ${ }^{18}$.

\footnotetext{
16 Określenie Władysława Mickiewicza. W. Mickiewicz, dz. cyt., s. 168.

17 Tamże.

18 Wielokrotnie pisała na ten temat Maria Prussak (m.in. w odniesieniu do liryku Snuć miłość): „Z brulionowym charakterem wierszy, nie publikowanych za życia poety, wydawcy nie uporali się do dziś. Pierwodruki Mickiewiczowskich ineditów, o czym także pisze Stefanowska, były poprawiane zgodnie z estetycznym wyczuciem pierwszych edytorów. Dopisywanie i przerabianie tekstu jest już traktowane jako edytorski
} 
Można powiedzieć, że Władysław Mickiewicz popełnił błąd edytorski, uznając oba fragmenty za jeden tekst, ale równocześnie należy zastanowić się nad jego decyzją, którą podjął jako czytelnik i interpretator manuskryptu. Jego rozstrzygnięcie wcale nie musiało być przypadkowe czy wskazujące na jakiś rodzaj ignorancji. Władysław Mickiewicz dostrzegł najprawdopodobniej powinowactwa obu zapisanych na kartce, choć oddzielonych przez poetę krzyżykiem, tekstów - powinowactwa trudne do określenia, ale istniejące, jeśli wziąć pod uwagę sens i wyobraźnię twórczą autora. W tradycji badawczej można zaobserwować kierunek odwrotny - oba te utwory publikowane i interpretowane są niezależnie od siebie, jako samodzielne, integralne wiersze $^{19}$. Współistnienie obu liryków jest znaczące. Władysław Mickiewicz sformułował komentarz, świadczący o próbach zrozumienia tekstu i uzasadnienia swoich decyzji edytorskich:

Stopniowanie wszystkich stworzeń podnoszących się od kształtów najgrubszych do ciągle doskonalszych, często zastanawiało Mickiewicza i prawdopodobnie marzył o poemacie de natura rerum, lecz nie ateuszowskim, jak Lukrecjusza, ale chrześcijańskim, opartym na postępie całej natury z woli Bożej wyrabiającej się i dźwigającej wszelkie istoty ku coraz wyższym szczeblom. Ilekroć brał się do wierszowania, walczył z wątpliwością, czy wolno mu odsłaniać pewne prawdy, a przy tym zachodziły wielorakie przeszkody: to prace w Kole z uczniami Towiańskiego, to rozprawy niesłychanie ciężkie z emigracją i coraz większe trudności materialnego bytu ${ }^{20}$.

Oba liryki: Drzewo, [Wstuchać się w szum wód głuchy...] zrodziły się $\mathrm{z}$ tego samego stanu mentalnego i twórczego, utrzymane są w jednej

anachronizm i w zasadzie się nie zdarza [...]”. M. Prussak, „Liryki lozańskie” i interpunkcja, w: tejże, Czy jeszcze stychać głos romantyzmu?, Warszawa 2007, s. 120.

19 Zob. Marian Maciejewski, „Rozeznać myśl wód...” (Glosy do liryki lozańskiej), „Pamiętnik Literacki”" 1964, z. 3. Przedruk w tomie: M. Maciejewski, Wrzucony do bytu otchłani. Liryka lozańska i jej konteksty, Lublin 2012; Adela Kuik-Kalinowska, Woda, wiatr i dźwięki świata „[Wstuchać się w szum wód gluchy...]”, w: Wiersze Adama Mickiewicza. Analizy, komentarze, interpretacje, pod red. Jacka Brzozowskiego, Łódź 1998; Teresa Rączka, „Przez fale rozeznać myśl wód". O romantycznych przedstawieniach rzeki w twórczości Adama Mickiewicza i Tarasa Szewczenki, Katowice 2011.

20 Władysław Mickiewicz, dz. cyt., s. 168-169. Uwspółcześniono pisownię niektórych wyrazów. 
tonacji lirycznej, w rytmie trzynastozgłoskowca. Oba są zbudowane z wyliczeń i kolejno po sobie następujących obrazów, które charakteryzują się dynamicznością oraz zapowiadają metamorfozy, zarówno w świecie zewnętrznym, jak i w rzeczywistości wewnętrznej. Poeta ujawnia głęboką, osobistą relację przede wszystkim z samym sobą, jakiś rodzaj gotowości na zmiany. Tę gotowość odnajduje także w różnych sferach obserwowanej przestrzeni. Obrazy w lirykach są pozornie przypadkowe, skojarzeniowe, ale konsekwentnie wyrażające pewien stan duchowy i psychofizyczny (trudno to jednoznaczne określić), który został zwerbalizowany w cytowanym już liście do Towiańskiego („uczucie swobody i mocy, bez żadnej myśli, bez kierunku, bez chęci”). W lirykach wyczuwalne jest napięcie wywołane być może oczekiwaniem na jakiś rodzaj puenty, która wyrażałaby sens, celowość i dynamizm metamorfoz. Konstatacja, choć przez samego poetę wyczekiwana, mogła wydawać się nieosiągalna, zbyt prosta w odniesieniu do natłoku myśli i odczuć, zbyt powierzchowna i niefrasobliwa w porównaniu ze stanem duchowym, $\mathrm{z}$ doświadczeniem życia i własnej osoby. Rolę konstatacji pełni w obu utworach (per analogiam) niedopowiedzenie, w nim właśnie spotęgowana została impresyjność wiersza, a także intymność lirycznego wyznania. Niedomówienie jest elementem wyrażającym sens egzystencjalny.

Ulotność i delikatność obrazów jest wspólna dla obu liryków, „łączy je" także osobista tonacja, choć wyrażona w formach nieosobowych (co wydaje się istotne). W obu utworach (centralnie) pojawia się analogiczny obraz poetycki wiatru, który jest ekwiwalentem tego, co dynamiczne, zmienne, bo o przemiany w lirykach chodzi. Wiatr, szerzej eoiczność jest tu źródłem nieokreśloności, zagadkowości, oddającej nie wprost stan emocjonalny i konkretny moment egzystencjalny, dla samego autora trudny:

„Gdy wiatr wionie, że nie wiesz, czy dziecko w kolebce...” (Drzewo);

„Dać się unosić wiatrom, nie wiedzieć gdzie lotnym...” ([Wstuchać się w szum wód gluchy...], podkr. E. Sz.-P.) 
Niewiedza jest deklarowana oraz spotęgowana w obrazach poetyckich, nie chodzi jednak o jej wymiar intelektualny, nie o poznanie, ale o rozpoznanie i to nie istoty żywiołów, lecz rozpoznanie, które dotyczy człowieka i znajduje „ujście” w poetyckich obrazach. Sąsiedztwo liryczne wiatru i niewiedzy wyraża poznawczą niemoc, niemożność udzielenia odpowiedzi na pytania, dotyczące istoty zjawisk, a także istoty samego siebie.

Wiatr współtworzy, buduje melancholijny nastrój obu wierszy. W liryku Drzewo staje się częścią opisu tytułowego drzewa, które tylko pozornie jest statyczne. Trudno nawet rozgraniczyć przywołane skrótowo szczątki wiadomych tylko poecie obrazów i rozpoznań, ale są to przywołania wystarczające, mieszczące się w ramach lirycznej przestrzeni intymności. Dynamizm i ruch sprawiają, że obrazy w obu lirykach nakładają się na siebie, w złożonym procesie recepcji, synestezyjnie łączą się poszczególne jakości i wrażenia, stąd ich trudna do określenia płynność. Poruszające się na wietrze drzewo podlega zmianom na oczach patrzącego: ,„...] liśćmi przebiera jak nóżki / Gdy wiatr wionie, że nie wiesz, czy dziecko w kolebce / Czy gąsienica". Nie wiadomo, czy drzewo zamiera, czy też obumiera, aby móc się odrodzić, zgodnie z cyklicznością natury.

Wiatr pełni istotną funkcję także w drugim liryku, jest żywiołowym, analogicznym, powietrznym odpowiednikiem szumu wód. Obraz poetycki składa się z synestezyjnych wrażeń: z dźwięków, dotyku, z odczuć i pragnień, których z jakichś powodów nie daje się nazwać, a tylko wyrazić: ,„wsłuchać się”, „dać się unosić”, ,zliczyć”. Wyrażone w taki sposób tęsknoty mają wspólny mianownik w osobie poety, który w impresyjny sposób wysławia swoją kondycję, a także ma poczucie, a zarazem pragnienie rozproszenia, rozpłynięcia się, ale nie w jakiejś nieokreśloności - raczej w doświadczeniu o charakterze głębokim, w doświadczeniu absolutnym - choć trudno określić to, co dla samego poety było niewyrażalne, mogące znaleźć wyraz i sens jedynie w lirycznej ,konkretyzacji”.

Płynność skojarzeń można by się odważyć nazwać lirycznym strumieniem świadomości, ponieważ to nie obrazy impresyjne są tu naj- 
ważniejsze (one wydają się nośnikami znaczeń), ale osoba i jej doświadczenie. Opisywane zjawiska ujęte w obrazy poetyckie zmieniają się jak w kalejdoskopie, zdają się być tworzone z pewnych stałych elementów i według stałych zasad, tak jakby ich cel i sens był podobny, ponieważ łączy je kondycja autora i jego sposoby czy też możliwości postrzegania $\mathrm{w}$ danym momencie jakiegoś wymiaru rzeczywistości.

\section{Drzewo}

Podstawę kompozycyjną w liryku stanowią płaszczyzny kolejno po sobie następujących skojarzeń, wyrażonych in statu nascendi, w akcie bezpośredniej percepcji wzrokowo-słuchowej, uruchomionej przez centralny obraz drzewa. Nie wiadomo, gdzie i w którym momencie kończy się percepcja zmysłowa i empiryczna, a zaczyna praca myśli i uczuć. Poeta dopuszcza pewien rodzaj „nieufności” wobec dostępnych środków nazywania swego doświadczenia, stąd być może kluczowe słowa kierowane do siebie: ,nie wiesz”, które zostały zhiperbolizowane i ,zwielokrotnione” poprzez nagromadzenie wyliczeń: „nie wiesz, czy dziecko w kolebce, czy gąsienica szybko mącąca nogami, czy wąż...”. O niczym nie można powiedzieć: ,wiesz”. To trochę tak, jakby pejzaż próbować odbierać z zamkniętymi oczami, z szumu drzewa odczytywać jego kształt. „Nie wiesz” tworzy dominantę znaczeniową, wszystko bowiem jest w trakcie przeobrażeń, dlatego stan wiedzy jest niemożliwy do osiągnięcia, dotyczy bowiem (zawsze) jakiegoś stadium rozwoju.

Tytułowe w swej lirycznej prezentacji drzewo jest niczym oś świata, zwłaszcza że pojawia się w wierszu słowo wąż (przywołujące obraz mitycznego drzewa poznania dobra i zła, występującego w łączliwości znaczeniowej z konstatacją: ,nie wiem”). Kierunek wertykalny wyznaczony w wierszu przez obraz drzewa odkrywa szczególną płaszczyznę znaczeń. Poeta unika dopowiedzenia, wyjaśnienia, tak jakby impresyjność była celem samym w sobie, a wiatr pełnił znaczącą funkcję „rozpoznawczą” w odniesieniu do jego własnego samopoczucia. Liryk jest otwarty, w tradycyjnym rozumieniu niedokończony, a nawet 
nie zaczęty; rozpoczyna się bowiem od spójnika „i”, czyli jakby od środka zdania, westchnienia, konstatacji.

Centralnym obrazem w wierszu jest starzejące się drzewo, znakami jego niszczenia zaś wydają się być: robak, „liście niejednakie”, „,barwista wróżba liszki” ,gąsienica”, „wąż”. Przemijalność drzewa jest tu przeniesiona na osobę podmiotu, zatem uwewnętrzniona, wyrażona przez poetę per analogiam w sposób introwertyczny, dotykająca samej istoty tożsamości piszącego. „Oko” i „ucho” to swego rodzaju receptory, umożliwiające dostęp do samego siebie; to właśnie poprzez sposób patrzenia i odczuwania tego, co wobec podmiotu zewnętrzne, może się ujawnić również to, co głębokie. Centrum poznania i rozpoznania jest bowiem ,ja”. Wiersz bezpośrednio staje się przestrzenią uświadamiania sobie własnej kondycji. Jest to obraz melancholijny, bo zawierający utrwalone w lirycznych obrazach „martwienie”, niszczenie, a zatem procesy związane z przemijaniem, zamieraniem, obumieraniem, z narodzinami i kolejnymi stadiami życia, zbliżającymi do kresu.

Drzewo „nieuleczalnie” zamiera być może po to, aby się odnowić, co byłoby spójne z obecnymi w wierszu obrazami dziecka, gąsienicy (stadium rozwoju) czy węża (odradzającego się poprzez zrzucenie skóry). Poeta wyraża stan niepewności wobec tego, co słyszy albo co mu się wydaje, że słyszy; tak jakby znaki, które odbiera, wcale nie dawały mu pewności, że są takimi, jakimi są w swej istocie. Być może dlatego unika konstatacji i podsumowań o charakterze jednoznacznym. Wanitatywny obraz drzewa (łagodzony przez zdrobnienia) w swej niedookreśloności, brulionowości, wywołuje zdumienie. Sens rodzi się dzięki semantycznej jednolitości lirycznych skojarzeń, oddaje jakiś rodzaj tkliwości, a przy tym zadumę i smutek, to wszystko, co mieści się w doświadczeniu vanitas. Robak toczący drzewo, liszka, gąsienica, „świecące się po wierzchu” liście „niejednakie” - to atrybuty wanitatywnej semantyki, istotne i charakterystyczne chociażby dla malarskich studiów martwych natur.

Przez pryzmat ostatniego w wierszu słowa-hasła: „wąż”, drzewo nabiera wysokiej rangi, staje się drzewem poznania, a raczej samopo- 
znania (rozpoznania), jednakże zdrobnienia, uszczegółowienia, zbliżają ten obraz ku sferze osobistej, a nie biblijnej czy symbolicznej (uogólniającej). Ta wanitatywność obrazu nie odnosi się tylko do zewnętrznych atrybutów, docelowo określa stan psychiczny doświadczającego go autora (brulionowy charakter utworu umożliwia przywołanie w tym miejscu właśnie osoby autora). To, co mityczne, otwiera to, co osobiste. Oko kontemplacyjne poety i ,oko wewnętrzne”, poznanie i rozpoznanie, patrzenie i dostrzeganie, fenomen i jego ontologiczna ranga mają swój wymiar egzystencjalny. Wanitatywność wpisana jest tu w organiczny cykl przeobrażeń, stanowi warunek życia (odradzania się) i śmierci. Zacierają się w liryku granice między tym, co życiodajne, a tym, co zapowiada śmierć. Liszka, dziecko, gąsienica, wąż - to świat w trakcie przeobrażeń, gdzie cykle: życia, narodzin, umierania, obumierania, zamierania muszą ze sobą współistnieć, ponieważ wzajemnie się warunkują ${ }^{21}$. Liryk pozbawiony jest tradycyjnej puenty, ponieważ to obraz poetycki zdaje się być od niej ważniejszy. Poprzez dynamikę melancholijnego doświadczenia jednostkowego; uczucia wyrażone w tekście, w zdrobnieniach, skojarzeniach i ich emocjonalnym „nieuporządkowaniu”, dynamicznie zmieniających się zaledwie zarysowanych obrazach; lirycznie wyrażone zostało wewnętrzne rozpoznanie, poczucie, doświadczenie własnej istoty (sobości), a także istoty bytu.

\section{[Wstuchać się w szum wód gluchy...]}

Podobnie jak Drzewo, również [Wstuchać się w szum wód głuchy...] ma charakter lirycznego wiersza-szeptu. Frazy są melodyjne i ryt-

${ }^{21}$ Jean-Charles Gille-Maisani trafnie rozpoznał sens psychologiczny wiersza Drzewo: „Nie wiadomo dokładnie, kiedy powstał krótki, niedokończony wiersz Drzewo. Mickiewicza dręczy problem dokonującej się indywidualizacji - jej projekcję odnajdujemy w wierszu. Ileż obrazów przeobrażenia pojawia się w siedmiu wersach! Zwróćmy uwagę na dwa problemy: a. podtekst etyczny («wysłużyło»), zgodny z hierarchią systemów Saint-Martina i Towiańskiego; b. przemiana jest niezakończona (dziecko ma urosnąć, gąsienica ma stać się motylem, a wąż - zmienić skórę), a jej wynik niepewny («nie wiesz, czy...»)". J.-Ch. Gille-Maisani, Adam Mickiewicz człowiek. Studium psychologiczne, przeł. Agnieszka Kuryś i Katarzyna Rytel, Warszawa 1987, s. 298-299. 
miczne, płynące w pozornym spokoju ,wyciszonych” obrazów lirycznych. Te szeptane marzenia poety mają analogiczną do wiersza Drzewo budowę, wyrażają kontekst psychiczny, mentalny; tęsknotę za czymś, co niewyrażalne. Słuchanie wód ma pozwolić „rozeznać ich myśl”, uniesienie przez wiatr ma umożliwić ,zliczenie każdego [jego] dźwięku”, „wnurzenie się w łono rzeki” ma pomóc spojrzeć na nią okiem ryby. Przy czym każdy z czasowników bezosobowych: wsłuchać się, dać się unosić, zliczyć, wnurzyć się zawiera w sobie aspekt dynamiczny i osobowy, oznacza nie tylko czynność, ale bezkompromisowe zaangażowanie osoby w tę czynność, utożsamienie jej z inną zupełnie materią zjawisk, które mogą być tylko pozorne, ponieważ wynikają z jakiejś potrzeby oderwania się, a może nawet rezygnacji ze swej własnej istoty. Nie sposób to wyrazić.

Marian Maciejewski uznał aspekt poznawczy za temat w liryku dominujący:

Można by [...] mówić o postulacie poznawania przyrody poprzez rozumową kontynuację i dopełnienie jej nieświadomych poczynań. Praktycznie rzecz sprowadza się do unifikacji podmiotu z percypowanym obiektem poprzez przyjęcie jego natury ${ }^{22}$.

Trudno zgodzić się z powyższą tezą. Nie jest to ,unifikacja” podmiotu i obiektu w celach poznawczych (rozumowych) - zbyt prywatnym tonem, z napięciem zostały te wersy wypowiedziane. Utożsamienie się $\mathrm{z}$ percypowanym obiektem jest pozorne, niemożliwe do osiągnięcia i ta niemożliwość jest w wierszu wyrażona poprzez nagromadzenie obrazów różnych żywiołów. Nie dochodzi jednak do unifikacji podmiotu z materią żywiołu, podmiot ciągle poszukuje obszaru pozwalającego na ,zakorzenienie” gdzieś indziej, w innym miejscu niż to, w którym się znajduje. Integralność osoby, świadomość tej integralności, uniemożliwia jednak unifikację z materią żywiołów, dlatego podróż ma charakter mentalny, a jej kwintesencją jest niekończące się

22 Marian Maciejewski, dz. cyt., s. 47. 
poszukiwanie i tęsknota; to tak, jakby pukać do różnych drzwi, ale nigdzie nie móc wejść.

W lirycznym stopniowaniu czynności pobrzmiewa tonacja wierszy lozańskich, dlatego m.in. nazywam liryki: Drzewo i [Wstuchać się w szum wód głuchy...] (z 1842 r.) oraz [Jak drzewo przed wydaniem owocu...] (z 1843 roku) mianem liryków polozańskich. Charakterystyczne dla przedlozańskich (do tego wątku jeszcze powrócę), lozańskich i polozańskich wierszy jest rozprzestrzenianie się wzroku, aby móc rozpatrzeć się w sobie, w tęsknocie odnaleźć samego siebie. Jednocześnie pobrzmiewa w utworach, które nazywam polozańskimi, jakaś nowa nuta, różna od lozańskiej czy przedlozańskiej.

W liryku [Wstuchać się w szum wód głuchy...] są naszkicowane jakieś etapy wtajemniczenia w wiedzę o sobie samym, trochę podobnie jak w wierszu [Snuć miłość], choć w polozańskim liryku tonacja nie jest tak „pozytywna”, nie kończy się finalnym osiągnięciem ideału (,snucie miłości” to proces dojrzewania duchowego).

Poszczególne etapy w liryku [Wstuchać się w szum wód głuchy...] wyznacza rytm kolejnych wersów:

1. „Wsłuchać [się] w szum wód głuchy, zimny i jednaki”;

2. „Przez fale rozeznać myśl wód jak przez znaki”;

3. „Dać się unosić wiatrom, nie wiedzieć gdzie lotnym”;

4. „I zliczyć każdy dźwięk w ich ruchu kołowrotnym”;

5. „Wnurzuć się w łono rzeki z rybami... / Ich okiem niewzruszonym jak gwiazda...".

Pragnienie, aby „wsłuchać się w szum wód głuchy, zimny i jednaki” jest sformułowaniem określającym czynność, która rodzi niepokój: wsłuchać się w to, co jest głuche i paradoksalnie milczące, niezmienne, jednakowe, jednostajne. Wynik tej czynności jest od razu wartościowany, tak jakby efekt poznania był z góry przewidziany, ale sama czynność „wsłuchiwania się” staje się czymś koniecznym i potrzebnym. Stałość wody, jej ,zimność”, ,jednakość” nawiązują do lozańskich motywów (wody wielkie i czyste), ale nie są z nimi tożsame. Następne pragnienie - aby „dać się unosić wiatrom, nie wiedzieć gdzie 
lotnym” i w tym ruchu ,zliczyć” każdy ich dźwięk, wyraża chęć oddalenia się z miejsca, w którym się jest (i to w szerokim znaczeniu), a nawet pragnienie rozproszenia $\mathrm{w}$ jakimś chaotycznym ruchu określanym jako „kołowrotny”. „Wnurzyć się w łono rzeki z rybami” - ta czynność również jest „niemożliwa”, bo w liryku zakłada się jakiś rodzaj trwania pod wodą. Sformułowanie ,wnurzyć się” z rybami znaczy coś innego niż np. ,zanurzyć się”.

Wiersz - jak wspominałam - nie jest dokończony w tradycyjnym znaczeniu. W brulionowym kontekście „urywkowość” jest znakiem, że analogicznych do wymienionych czynności można by wymienić znacznie więcej, nieskończenie wiele, i nie prowadziłyby one ku jakiemuś określonemu celowi, ponieważ stanowią cel sam w sobie. Wody, fale, wiatry, tworzą dość jednolity melancholijny obraz, a istotą tej melancholii jest uświadomiona sobie „niemożliwość” i ograniczenie. Wiersz wyraża rozpoznanie, ale nie tyle własnej podmiotowej kondycji i wynikających z niej ograniczeń poznawczych, ile raczej tożsamości osoby, dlatego nie o poznanie chodzi, ale o wyrażenie tej najbardziej osobistej z wszystkich relacji, czyli relacji z samym sobą.

Marian Maciejewski w Glosach do liryki lozańskiej pisał o funkcjach poznania zmysłowego w liryce Mickiewicza (również w tym liryku); pokazywał zmiany w sposobie ujmowania tych treści, m.in. w wierszu [Wstuchać się w szum wód gtuchy...]:

[...] poznanie zmysłowe będzie teraz etapem wstępnym, przygotowującym „materiał” intelektowi, bo tylko myślą można „,rozeznać myśl wód”, kształty zewnętrzne będą tylko znakami: „I przez fale rozeznać myśl wód jak przez znaki" ${ }^{23}$.

Czy w innym miejscu:

[...] w nowym, „mistycznym” poznaniu” - podobnie jak to można obserwować w liryce mistycznej Słowackiego - ważne są i niektóre wybrane kształty konkretne, jako szczególny rodzaj „znaków”. Tak np. w komen-

23 Marian Maciejewski, dz. cyt., s. 41. 
towanym wierszu „szokuje” (jak na liryk mistyczny) konkretność stwierdzenia (realizm obserwacji)... o rybie patrzącej nieruchomym okiem. [...]

Tak, ale ta fizyczna czy fizjologiczna prawda wytwarza stylistyczną możliwość skojarzenia z gwiazdą. Dla rzeczy zwykłej otwiera poeta perspektywy kosmiczne i tą drogą chce z niej „,wyłuskać” najważniejszy sens. Metaforyczna korelacja świata zwierzęcego z przyrodą wielką i poznającym podmiotem przynosi w artystycznym efekcie postulat wszechjedni w akcie poznawania ${ }^{24}$.

W zasadzie trudno w tym wierszu odnaleźć przygotowanie „materiału" intelektowi, ponieważ nie o intelekt chodzi. Myśl w liryku jest wprawdzie jakością intelektualną, ale wobec podmiotu zewnętrzną („myśl wód”), a rozeznać tę myśl, nie znaczy tylko tyle, co intelektualnie ją posiąść. Zwracała na ten aspekt uwagę Maria Cieśla-Korytowska $^{25}$. Maciejewski, zdaje się, nie oceniał wysoko wartości tego utworu. Świadczą o tym między innymi słowa, jakie napisał na temat „unifikacji podmiotu z percypowanym obiektem poprzez przyjęcie jego natury”, stwierdził również: „W konsekwencji zapatrywań romantycznych nie jest to znów taka wielka rewelacja"26. Poza tym Maciejewski zacytował w przypisie pastisz wiersza Mickiewicza autorstwa Kazimierza Wyki, mało tego - uznał ten pastisz za dobry.

\section{Tamże.}

25 O niemożności poznania wyrażonym właśnie w tym liryku pisała Maria Cieśla-Korytowska: ,[...] Jest to zarazem wiersz podsumowujący całkowicie i ostatecznie ten nurt, który idzie od Szanfarego, Farysa, Bajdarów, a którego sensem jest pragnienie bycia uniesionym przez wiatr, porwanym przez rzekę po to, by w zjednoczeniu z nią doznać istoty życia takiej, do jakiej podmiot zdaje się dążyć, to znaczy pozbawionej tak naprawdę pracy myśli. Fragment I przez falę rozeznać myśl wód jak przez znaki nie powinien nas zmylić; tu nie chodzi o poznanie, lecz o zjednoczenie czy też o poznanie przez zjednoczenie z naturą, połączone z przenoszeniem się w czasie, miejscu, z dążeniem już nie do celu, lecz do wieczności, niezmienności, jakie mogą ofiarować tylko wiatr, woda, przyroda. Podróż bowiem jest wedle autora Pielgrzyma aktem doniosłym, jest gestem egzystencjalnym, aktem odmiany życia”. M. Cieśla-Korytowska, ,Uciec $z$ duszą na listek...", w tomie: Autor, autor!, Kraków 2010, s. 40. Por. M. Cieśla-Korytowska, „Uciec z dusza na listek...”. O Mickiewiczowskiej podróży, w: Dziedzictwo Odyseusza. Podróż, obcość i tożsamość, identyfikacja, przestrzeń, pod red. Marii Cieśli-Korytowskiej i Olgi Płaszczewskiej, Kraków 2007 (pierwotna wersja tekstu).

26 Marian Maciejewski, dz. cyt., s. 47. 


\section{Trudno zgodzić się, że}

autor pastiszu [...] dał zupełnie prawdopodobną kontynuację [wiersza Mickiewicza]. Tekst Wyki finalizuje akt poznawczy „w duchu schellingiańskim" "27,

Dlaczego Maciejewski zacytował tekst Wyki? Pastisz odbiera utworowi Mickiewicza całe jego napięcie duchowe, wpisane weń intymne wyznanie i dramatyzm. Wyka dowolnie czerpie obrazy z obu wierszy polozańskich, a także je interpretuje i wartościuje:

\section{$[\ldots]$}

[Wnurzyć się w łono rzeki z rybami], co płyną

I złotą łuskę kują, gdy tkwią nad głębiną,

[Ich okiem niewzruszonym jak gwiazda] spozierać,

Duszy ruchem ich szukać, kiedy pocznie wzbierać

I przez potok zagada; w pierś wziąć przyrodzenia

Każdy listek, robaczek każdy, kiedy się przemienia

W liszkę, być onym, co w obłoku świata czyta dzieje

I krzewi w swym sumnieniu, co Bóg zewsząd sieje -

Aż mocą porażony, przestał być człowiekiem

I z szumem wód przeminie ciemnym, cichym wiekiem ${ }^{28}$.

Pastisz Wyki ośmiesza oryginalną frazę Mickiewicza. W utworze [Wstuchać się w szum wód głuchy...] poznanie - pomimo wysiłków nie jest możliwe; nie jest nawet możliwa ,unifikacja podmiotu z percypowanym obiektem”, nie jest możliwe „przyjęcie jego natury”. Obrazy Mickiewicza mają siłę lirycznego argumentu, ale ich wydźwięk jest wręcz autodestrukcyjny. Tonacja wiersza jest ciemna: „wody głuche”, szum ,zimny jednaki”, wiatry „nie wiadomo gdzie lotne” w „ruchu kołowrotnym”, oko ryby - ,niewzruszone”. Świat jest tutaj wartościowany negatywnie, niedostępny w jakimś sensie, wręcz niemy, lepszy jednak chyba - w mniemaniu poety - niż ten, z którego chce się uciec,

\footnotetext{
27 Tamże, przypis 41 na s. 47.

28 Kazimierz Wyka, Duchy poetów podsłuchane, Kraków 1962, s. 29.
} 
niż wewnętrzny świat osoby, określany i wartościowany w danym, a więc konkretnym momencie życia.

Marian Maciejewski napisał:

Autor pastiszu korzystając z materiału słownikowego i obrazowego innych liryków lozańskich (Snuć miłość, Drzewo) dał zupełnie prawdopodobną kontynuację. Tekst Mickiewicza-Wyki każe widzieć w tym dopełnionym utworze daleko posuniętą analogię z lirykiem Nad wodq wielka i czysta... ${ }^{29}$.

Interesująca jest (zrealizowana przez Wykę) potrzeba dokończenia tekstu. Brulionowość (w historii recepcji tekstu) stanowiła jego usterkę, wadę materii poetyckiej, podczas gdy właśnie niedokończoność czy zerwanie frazy mają w liryku kluczowe znaczenie.

W lirycznych nawiązaniach do konkretu materii żywiołów postawa poety jest introwertyczna. Dochodzi w tym liryku do jakiegoś rozpraszania siebie po różnych obszarach świata, na który się patrzy, którego się doświadcza. Wypowiadzane w liryku marzenia świadczą raczej o potrzebie ekspiacji, nie eksploracji rzeczywistości. Ta odśrodkowość prowadzi do rozpoznania, ale nie istoty zjawisk otaczających (zewnętrznych), lecz własnego pragnienia, by między innymi spojrzeć „niewzruszonym” okiem ryby - okiem innym niż własne. To głęboka i wyrazista metafora. Oko ryby jest „niewzruszone”, ponieważ nie posiada powieki, jest okiem zawsze otwartym, o stałym kącie widzenia, a zatem jest okiem nieruchomym. Wyraz: „niewzruszone” przywołuje także znaczące słowo: wzruszenie. Zostaje tu zatem sformułowana jakaś ważna liryczna konstatacja o randze ontologicznej: „oko niewzruszone" - ,jak gwiazda". Jest to inne oko niż w Romantyczności, ale i poeta bada świat inaczej niż „wtedy”. Nie rozstrzyga, kto ma rację, którą opcję wybrać, co bardziej lub mniej do niego przemawia; nie o poznanie, raczej o doświadczanie tu chodzi. Poznanie przyjmuje kierunek: od podmiotu ku obiektowi poznania, doświadczanie ma kierunek odwrotny (od obiektu do samego siebie). „Oko niewzruszone jak

\footnotetext{
29 Marian Maciejewski, dz. cyt.
} 
gwiazda", to kolejny argument określający tonację doświadczanego świata, tworzącą jedność logiczną i nastrojową z ,,szumem wód głuchym”, ,zimnym”, ,jednakim”, z wiatrami „,nie wiedzieć gdzie lotnymi”, z „wnurzeniem się w łono rzeki”. Oś wertykalna łączy „głąb” (oko ryby) z punktem w kosmosie (gwiazda). Linia wertykalna przechodzącą przez te dwa punkty wyraża jakiś rodzaj doświadczenia nieskończoności („uczucia nieskończoności”) w takim znaczeniu, w jakim to wyraził Stanisław Kostka Kłokocki w „Pamiętniku Naukowym" z 1819 roku:

Jakieżkolwiek wyobrażenia człowiek sobie czyni siebie samego i świata, widzi siebie zawsze jak istotę skończoną wśród nieskończoności.

Czy to świat jest całością istnień (egzystencji) i połączeniem istot wszystkich, czy też on jest tylko zbiorem wszelkich zjawisk (fenomenów) dotykających lub dotknąć mogących zmysły; czy świat jest jedyną substancją, której wszystkie istoty niezliczonymi są szczególnie modyfikacjami, lub że jest zebraniem substancji wszystkich ściśle z sobą połączonych i działających jedne na drugie; czy świat jest dlatego że jest, lub że jest pod warunkiem bytu innej istoty niepodległej i będącej samej przez się; czy ta istota oddzielną jest od świata, lub jest duszą wszystkiego: we wszystkich tych systemach, z których jedne są zgodne z prawami rozumu, drugie tym prawom przeciwne, zawsze jednak znajdziemy się pośród nieskończoności ${ }^{30}$.

Czy inny fragment korespondujący $\mathrm{z}$ tęsknotami wyrażonymi w liryku:

Jesteśmy więc i będziemy zawsze istotami skończonymi wśród nieskończoności. Idzie za tym, że znać będziemy istoty skończone i że nie poznamy nigdy nieskończoności, gdyż ten, który by ją poznał, sam byłby nieskończonym. Lecz skoro nasz rozum daje nam ideę nieskończoności i uznać nam ją każe, wiedzieć tedy zawsze będziemy, że jest nieskończoność i dosięgnąć jej usiłować przez nieokreśloność zechcemy. Mając siły

${ }_{30} \mathrm{Kł...} \mathrm{[Stanisław} \mathrm{Kostka} \mathrm{Kłokocki],} \mathrm{O} \mathrm{idei} \mathrm{i} \mathrm{uczuciu} \mathrm{nieskończoności} \mathrm{[Fragmenty],} \mathrm{w:} \mathrm{Idee}$ programowe romantyków polskich. Antologia, oprac. Alina Kowalczykowa, wyd. 2 uzupełnione, „BN” I, 261, Wrocław 2000, s. 30. (Komentarz do tego tekstu napisał Czesław Zgorzelski, Romantyzm w Polsce, w: Od Oświecenia ku romantyzmowi i współczesności, Kraków 1978). 
skończone nie potrafimy nigdy działać na nieskończoność, lecz ona wywrze dzielność swoją na nas; jako części nieskończonej całości obdarzone siłą poznawania nie będziemy nigdy mogli usunąć się spod jej skrytej i głuchej władzy [...]. Nieskończoność, czyli świat niewidzialny, którego świat widzialny jest szczególnie jakim obrazem (type) a przynajmniej cząstką, nigdy stać się nie może przedmiotem znajomości ludzkich, ale być może i jest w rzeczy samej przedmiotem postrzeżeń niewyraźnych, żądz, przeczuciów człowieka, i okazuje przytomność i czynność swoją w wielkiej liczbie wrażeń i działań duszy ludzkiej ${ }^{31}$.

Sformułowana w ten sposób kategoria „nieokreśloności”, pomimo swego enigmatycznego charakteru, pozwala dostrzec potrzebę wysłowienia owej nieokreśloności w liryce, tam ona się ujawnia. Nieokreśloność w lirykach takich jak: Drzewo i [Wstuchać się w szum wód gtuchy...] została osiągnięta poprzez brulionowość: zerwania frazy, rytmu, pozorną niespójność obrazowania i znaczenia, poprzez niedomówienia, przemilczenia, metafory, użyte ze względu na niemożność wyrażenia myśli w postaci dyskursywnej, odnoszące się bezpośrednio do istoty człowieka.

Wiersz ma charakter melancholijnego zwierzenia, w którym samopoznaniu towarzyszy jakiś rodzaj rezygnacji. Ten wewnętrzny niepokojący aktywizm, ucieczki, planowane ,wyprawy” niemożliwe z wiatrem, wodą, falami stają się źródłem samopoznania, zostały przeciwstawione jakiemuś rodzajowi pasywności wewnętrznej. Nie są wyprawami w celach doświadczenia istoty bytu, rodzą się być może z jakiegoś rodzaju bólu i rozpaczy. Oba wiersze, o których tu mowa (objęte wspólnym autografem), naznaczone są stygmatem melancholii, czymś w rodzaju żałoby. W jednej rozbudowanej frazie, w jednym zdaniu zawarte zostało melancholijne marzenie o wyjściu, przeobrażeniu, a nawet rozproszeniu. Melancholia została skonkretyzowana w obrazowej metaforze „niewzruszonego” oka ryby, jednakże pozbawiona jest tu tkliwości czy łagodności, jest wzniosłą melancholią, zrodzoną z samoświadomości oraz pewnego rodzaju samotności, którą

\footnotetext{
31 Tamże, s. 31-32. Podkr. E.Sz.-P.
} 
Mickiewicz nazywał „niepodległą”, zgodnie ze słowami, które miał wypowiedzieć: „Łatwo jest na świecie żyć wedle opinii świata, łatwo jest w samotności żyć wedle naszej, ale wielki jest ten, kto wśród tłumu trzyma z doskonałą słodyczą niepodległość samotności" 32 .

Podobne obrazy i myśli Mickiewicz wyraził już w liryku z 1832 roku Do Samotności, w którym ten właśnie stan określił słowami: „Tyś mój żywioł":

Samotności! do ciebie biegnę jak do wody

$\mathrm{Z}$ codziennych życia upałów;

$\mathrm{Z}$ jakąż rozkoszą padam $\mathrm{w}$ jasne, czyste chłody

Twych niezgłębionych kryształów.

$[\ldots]^{33}$

W obu lirykach dostrzegalne jest pewne podobieństwo motywów i znaczeń wyłaniające się z porównania dwóch liryków, ale interesująca jest różnica. Już ten przykład pokazuje, że liryki pozostawione w brulionach (do nich należy również Do Samotności), mają swoją specyfikę, nawet w ewolucyjnym ujęciu. Można zaryzykować stwierdzenie, że późniejszy wiersz jest powrotem do pewnych obrazów, sformułowań, twierdzeń:

Tyś mój żywioł: ach, za coż te jasnych wód szyby

Studzą mi serce, zmysły zaciemiają mrokiem,

I za coż znowu muszę, na kształt ptaka-ryby,

Wyrwać się w powietrze słońca szukać okiem?

W tym obrazie lirycznym istnieje w porównaniu z późnym wierszem różnica znaczeń (bardzo ważna). W utworze Do Samotności jest próba i konieczność wyrwania się w powietrze, ku słońcu, w wierszu późniejszym: ,wnurzenia się w łono rzeki” i błądzenia w materii żywiołów powietrznych, bez wyraźnego kierunku, bez jakiejkolwiek na-

32 [Zdania i urywki ogłoszone przez Władystawa Mickiewicza], w: Adam Mickiewicz o życiu duchowem, z pism, przemówień i listów zebrał Stanisław Pigoń, Warszawa-Lódź 1922, s. 123.

33 Adam Mickiewicz, Wiersze, dz. cyt., s. 341. 
dziei na znalezienie jakiegoś miejsca dla siebie. Wyrazem swego rodzaju wolności, siły witalnej w utworze wcześniejszym jest obraz ptaka-ryby, który można rozumieć jako konstrukcję metaforyczną. Ptak-ryba jest istotą przynależną dwóm żywiołom, można ją również rozumieć w odniesieniu do rodziny ryb ,latających”, zwanych ptaszorami (Exocoetidae). Wydaje się, że inny jest sens wyrażonych w obu utworach pragnień; w obu przypadkach, pomimo jakże odmiennego statusu podmiotu, materia żywiołów pozostaje „obca” i „niedostępna”. Status „wygnańca” określa sytuację egzystencjalną poety, a w zasadzie jej rozpoznanie (zdefiniowanie). „Samotności! do ciebie biegnę jak do wody..." to pragnienie osiągnięcia pewnego stanu psychofizycznego, który raptownie (i to $\mathrm{w}$ obu lirykach) prowadzi jednak do doświadczenia głębszego niż wstępnie przez poetę założone, do rozpoznania samotności, której wymiar nie jest już czasowo określony i wyznaczony wyborem poety (ucieczka w samotność przed światem, codziennością), ale jest stanem egzystencjalnym, czyli rozpoznaniem swojej kondycji jako człowieka. Jest to kondycja „wygnańca”, bo to, ku czemu poeta zmierza, i to, czego pragnie, pozostaje niedostępne i nieosiągalne. Nawet żywioł samotności pozostaje w jakimś sensie niedostępny, podobnie jak żywioł wody:

I bez oddechu w górze, bez ciepła na dole,

Równie jestem wygnańcem w oboim żywiole.

Samotność, paradoksalnie, pomimo tej całej gamy uczuć zawartej w wierszach Do Samotności i [Wstuchać się w szum wód głuchy...], ma wymiar konstytutywny dla rozwoju tożsamości osoby, dla wszelkich prób wysłowienia poczucia własnej tożsamości.

Z psychologicznego punktu widzenia istnieje jednak bardzo cienka granica dzieląca samotność jako upragniony stan wolności, będący schronieniem przez szeroko pojętą rzeczywistością, od samotności będącej wygnaniem, choć to tylko swobodna myśl, w utworach sens jest głębszy. 


\section{Brulionowe liryki ,polozańskie"}

Liryki Drzewo i [Wstuchać się w szum wód głuchy...] można nazwać ,ppolozańskimi” z wielu powodów, przede wszystkim dlatego, że w sferze poetyki występują w ścisłej łączności z lirykami określanymi mianem lozańskich, oddają - pomimo różnic - rozpoznany przez Zofię Stefanowską stan świadomości czy nawet samoświadomości poety, „rozpaczliwy głód poznania”. W literaturze przedmiotu funkcjonuje już sformułowanie: liryki przedlozańskie, których powstanie sięga do wcześniejszych liryków emigracyjnych Mickiewicza ${ }^{34}$. Na wspólnym autograficznym arkuszu, (podobne jak niektóre wiersze lozańskie i dwa polozańskie) zapisane zostały liryki z 1836 roku, które Zofia Stefanowska określiła mianem ,wielkich liryków”:

W lipcu 1836 istniały już - jak przyjmuje większość badaczy - zapisane na jednej kartce papieru wielkie liryki: Broń mnie przed soba samym, Pytasz, za co Bóg trocha sławy mnie ozdobit, Gęby za lud krzyczace, istniało zapewne już Widzenie. Wiersze - trzeba to zauważyć - całkowicie różne od dydaktyki Zdań i uwag, wiersze szarpane niepewnością, świadomością własnego grzechu, rozpaczliwym głodem poznania ${ }^{35}$.

Określenia: przedlozańskie, lozańskie, polozańskie wydają się uzasadnione i mogą okazać się ważne w badaniach nad rozwojem liryki Mickiewicza. Pomiędzy poszczególnymi lirykami dostrzegalne są analogie w tonacji lirycznej, na płaszczyźnie procesu twórczego, sposobu notowania, ale także znaczące różnice. Zgorzelski dostrzegał te analogie pomiędzy lirykami, które nazywam polozańskimi, a wierszami z okresu parysko-lozańskiego. Kartka z lirykami Drzewo oraz [Wstuchać się w szum wód...] przypominała poetykę zapisu wierszy, które nazywamy lozańskimi. Nie chodzi tu o ujednolicenie liryczne,

34 Żal rozrzutnika wielokrotnie był wprowadzany w krąg lozański. Zob. Julian Przyboś, Żal rozrzutnika, w: Czytając Mickiewicza, Kraków 1950; Marian Maciejewski, ,,Rozeznać myśl wód..." (Glosy do liryki lozańskiej), dz. cyt.; Juliusz Kleiner, Studia inedita, Lublin 1964; Dariusz Seweryn, O wyobraźni lirycznej Mickiewicza, Warszawa 1996.

${ }^{35}$ Zofia Stefanowska, dz. cyt., s. 346. 
ale powinowactwo. Sposób wyrażania, sposób ujmowania istotnych dla poety jakości, sprawia, że o wierszach przedlozańskich, lozańskich i polozańskich możemy mówić jako o lirykach w czystej postaci. Wacław Borowy i Leon Płoszewski w Wydaniu Narodowym (1949), umieścili liryki Drzewo i [Wstuchać się w szum wód głuchy...] obok siebie (jeden pod drugim) w dziale Wiersze różne, po tzw. [Nowych zdaniach i uwagach]. Decyzja Borowego jest słuszna i interpretacyjnie znacząca, dotyczy bowiem wierszy, których nie należy rozdzielać w płaszczyźnie lektury. W niektórych edycjach oba wiersze polozańskie były umieszczane pośród liryków z okresu parysko-lozańskiego, a zatem włączane w ich obręb. W innych zaś, na przykład w Wyborze poezyj Mickiewicza wydanym przez Czesława Zgorzelskiego w 1986 roku w serii „Biblioteki Narodowej”, jeden z nich (Drzewo) został pominięty.

Kolejność i miejsce zamieszczania wierszy wynikają z zajmowanego przez edytorów stanowiska interpretacyjnego, jednocześnie kształtują sposoby lektury oraz wyznaczają style ich rozumienia. Układ wierszy zmienia się w zależności od wydania i decyzji danego edytora, dlatego tak ważny wydaje się powrót do autografów oraz do nawarstwianych w procesie historycznoliterackim komentarzy.

\section{Summary \\ A sheet saved from fire. Adam Mickiewicz's post-Lausanne lyric poetry [liryki polozańskie] (Drzewo and [Wstuchać się w szum wód gluchy...])}

The article is an interpretation study of two lyric poems by Adam Mickiewicz (Drzewo and [Wsłuchać się w szum wód głuchy...], 1842). It grows out of an analysis of a lost manuscript and the history of the above-mentioned poems' editions (including commentaries), as well as the notebook romanticism [romantyzm brulionowy] concept developed by the author. This concept encapsulates the inedita and creates a separate sphere in the epoch's literary art and aesthetics. 